Article

\title{
The Public-Private Dichotomy in Fascist Corporativism: Discursive Strategies and Models of Legitimization
}

\author{
Maurizio Cau \\ Istituto Sorico Italo-Germanico, Fondazione Bruno Kessler, 38122, Trento, Italy; E-Mail: mcau@fbk.eu
}

Submitted: 14 October 2016 | Accepted: 21 November 2016 | Published: 15 March 2017

\begin{abstract}
The twentieth century starts with a rediscovery of the collective dimension that legal modernity had compressed. The vivid debate that came with the fascist corporatist experiment is an interesting observatory that lets us read this process against the light. According to the major part of Italian legal culture the corporatist cultural project seems to forewarn a new framework of the connections between public and private spheres, state and society, law and economics, statism and pluralism. Corporatism, which did not intend to build a non-statual model of authority, was an answer to the need to attribute legal value and legal autonomy to economic and social actors that weren't adequately represented in the political and normative circuit. The paper is aimed at retracing some of the discursive strategies that characterized the corporatist experiment and the different legitimization models that were proposed by legal theory in order to rebuild the dichotomy between public and private spheres.
\end{abstract}

\section{Keywords}

corporatism; fascism; legal theory; legitimization

\section{Issue}

This article is part of the issue "Legitimization of Private and Public Regulation: Past and Present", edited by Klaus Dieter Wolf (Peace Research Institute Frankfurt, Germany), Peter Collin (Max Planck Institute for European Legal History, Germany) and Melanie Coni-Zimmer (Peace Research Institute Frankfurt, Germany).

(C) 2017 by the author; licensee Cogitatio (Lisbon, Portugal). This article is licensed under a Creative Commons Attribution 4.0 International License (CC BY).

\section{Defining the Field of Inquiry}

This paper focuses on a particular case of "public-private regulation" (Collin, Bender, Ruppert, Seckelmann, \& Stolleis, 2014) the form of it advanced by Italian fascism via corporativism, amid contradictions and inconsistencies. Fascist corporativism was a major experiment in reorganizing normativity, the aim being to create a juridical area where new form could be given to the traditional dichotomy between public authority and the private sphere.

This is an elusive phenomenon. Corporativism is an ambiguous notion/praxis (Schmitter, 1974; Tarello, 1988) in which the relationship between theory and practice is far from linear. I shall concentrate on the conceptual and doctrinal side to fascist corporativism, since that is where we see most explicitly the legitimating rhetoric used in preparing, accompanying, commenting and criti- cising that attempt to revise the political and legal set-up enacted between the mid-1920s and the early 1940s.

I shall be referring to corporativism as a historical phenomenon that was typical of Europe between the two wars, focusing on the Italian case which has made corporativism a kind of cradle. Broadly speaking, corporativism is "a way in which political power can reframe in a society invaded by social organizations which jeopardize the traditional closed structure of the State" (Cassese, 2012b, p. 96). I shall explicitly not be going into the specialist sense attached to the term by political science from the 1970s on, whereby corporativism was seen as a useful model by which to analyse certain features of mature capitalist societies (Cerasi, 2001; Schmitter, 1992; Stolzi, 2009; Tarello, 1979).

As historians have often pointed out (Gagliardi, 2010; Mazzacane, 2002; Mazzacane, Somma, \& Stolleis, 2005; Santomassimo, 2006; Stolzi, 2007), there developed a 
telling gap between the institutional reality of fascist corporativism and the enormous intellectual investment that accompanied it. Legal science at that time produced a minutely argued commentary on the corporative reformulation of the State. Such thinking made no significant impact on the concrete decisions of the regime, but nonetheless forms a fascinating window onto the various discursive strategies that underpinned the fascist legal system presented by its proponents as a breakthrough on traditional forms of state-oriented rule of law.

This was far from the case, but at any rate to begin with (and on paper, at least) corporativism was a legal system that seemed to inject regulatory independence into organised forms of private interest. It thus set up a normative stepping-stone between the two traditional poles of legal dialogue: the private and the public (Stolzi, 2012c). As recently described, "in general legal theorists interested in promoting the nascent corporatistic order saw it as an opportunity, not only to reflect on trade union and production relations, but also, in more general terms, to provide an account of relations between the individual, state and social organizations" (Stolzi, 2014, p. 151).

But it soon became apparent that an experiment which theoretically promised to etch away the stateoriented rule of law and redistribute sovereignty within organised society would not actually enter into competition with the State, but would reconfirm it in its supremacy.

Theoretically speaking, corporativism was a latenineteenth century development within European social Catholicism-as with Ketteler, Vogelsang, la Tour du Pin, de Mun, Toniolo-(Santomassimo, 2006, pp. 86-91; Schiera, 2005, pp. 44-47; Vallauri, 1971, pp. 10-64) and French solidarism - as with Durkheim, Duguit, Bonjour(Laborde, 1996; Riquelme, 2010). These sought to readjust relations between the State and society so as to give greater independence (including normative independence) to social dynamics. The fascist experiment soon scotched such aspirations and instead of decreasing the gap between State and individual, gave new centrality to state authority.

However, regime rhetoric was full of the subject of organized groups enjoying regulatory autonomy, insisting (both in intellectual argument and in public discourse) that a third area of law be created in which the identity of State power might be redefined and the ambit of political decision-making thrown open to the various social groups (Stolzi, 2014, pp. 154-160). Such legislative independence soon proved void in point of fact, being rapidly absorbed into the state mentality of fascism, but it did leave its mark on the language of fascist juridical science.

It is interesting to trace some of the main staging posts by which theoretical legitimization was given to corporativism, and how it would every so often be pre- sented as a kind of self-government by society, an opportunity to pick up true post-1789 revolutionary values, a solution by which the gap between State and private citizen could be shortened and the outline of sovereignty readjusted.

\section{Corporativism as a Reaction to Crisis of State}

Before weighing the role of the public/private dichotomy in the various interpretations of corporativism, we should do well to place the phenomenon in its historical context. The century had begun with rumours that the traditional model of State-based rule of law was facing a crisis. What was in crisis was the image of liberal bourgeois society: the society of the Code, hinging on property and freedom of negotiation. Two sovereign bodies stood opposed: the individual in the field of property and economic action, and the State in the field of command and the community. Society-structured into unions, parties, leagues and associations-was hemmed between these two dimensions. In other words, bourgeois society had buried the "communal" and "social" in the State, obliterating them inside a single political entity envisaged as a person (Grossi, 2012, p. 14; Marchetti, 2006).

One of the first and most astute analyses of this distortion of State structure was provided by Santi Romano. In his well-known Lo Stato Moderno e la Sua Crisi (1909) he described the gradual eclipsing of the State, browbeaten by a social movement "governed by laws of its own" and "antagonistic in attitude towards the State" (Romano, 1950) ${ }^{1}$. The mounting claims of the professional associations and new social forces which Romano described as corporativism and trade-unionism, were bringing about no less than the "decomposition of the modern State".

As he would confirm in his 1918 study, L'Ordinamento Giuridico, which outlined his institutionalist theory, the legal expert was up against pressure from the collective dimension beyond (and to some extent above) the State. Hence Romano's bid (he was not alone) to recover a series of "public" areas of society detached from the power dimension of the State. The plural nature of society needed to be reinstated and its normative potential progressively reappraised.

The war had made it clear that normativism was no longer an adequate instrument to govern the new model of society. Special wartime legislation had set in place a new equilibrium between the State's ability to intervene in the dynamics of the economy and the inviolability of private independence. ${ }^{2}$ By contrast, the complex relations between capitalism and mass society had changed some of the paradigms of traditional legal doctrine. One thinks of the entrepreneur, a forcibly emerging figure who hardly fitted in with the classic patterns of private

\footnotetext{
${ }^{1}$ The literature on Romano's inaugural address is copious; one may cite Grossi (2011), Cassese (2012a), Ripepe (2012), Luongo (2013).

${ }^{2}$ An illuminating analysis of this point was made by Filippo Vassalli in his inaugural lecture On Wartime Legislation and the New Confines of Private Law in November 1918 (Vassalli, 1939).
} 
property, or the pressure to detach labour contract from the bounds of legal negotiation and to include the collective dimension in the dynamics of labour law (Cazzetta, 2007; Grossi, 2000). The bid for more pluralistic articulation of society increasingly pressurized the State. It was to these stimuli that the corporative experiments ushered in during the 1920 s responded.

In the case of Italy this process took a line all of its own. Compared with the Weimar experience, Fascism's was branded as pseudo-corporativism (Grossi, 2012 , p. 16) owing to the rapid list towards state authoritarianism. Some of the closest observers nonetheless noted the pluralistic vein of all corporativist structure and gave this its due, at least in theory.

The need to make the State fit into the new social reality demanded that not just the individual but organised social groups be given a central importance. New tools of legislation and experiments in institutional engineering were required to redress the relationship between State and organised interests, between politics and the economy, public and private. As Giuseppe Bottai, a charismatic intellectual leader under Fascism, remarked in 1928: "one may not adore the masses, but one cannot reject them, one cannot ignore that they are here to stay" (Bottai, 1934, p. 32).

In short, society was no longer "the mechanical sum of its individuals" (Panunzio); it was forming into subgroups demanding a more active, independent role from a legal point of view, among others. The State as inherited from the French Revolution, in which all legal phenomena boiled down to the relationship between State and citizen, had vanished out of all recognition. One of the leaders in the debate on building the "new State", Sergio Panunzio, recalled: "Its pure, majestic, classical and statutory line has snapped and gone awry. Nor can it be put back to its original form. Absurd: only the wreckage remains of the old idea and old form of the State. The State grows dim and takes a step back; what emerges and comes to the fore is Society" (Panunzio, 1987, p. 157). The "State of individuals", as he remarked in his inaugural lecture at Ferrara University in November 1922, would give way to the "unionised State and inter-union, supraunion law" (Panunzio, 1987, p. 139).

What ratified the "new model of social organisation", literally and intentionally, was the Charter of Labour of 1926 (Carta del Lavoro) which ushered in the fascist experiment with corporativism. It established a unified trade-union, introduced collective bargaining, and banned strike action or lock-out. Spontaneous social formations were denied any autonomous legal recognition, though on paper and in increasingly authoritarian terms it did signify some acceptance of the intermediate role of a socio-political compact. The basic assumption was that the trade-union was recognised as the new way of structuring the social sphere, which therefore entailed a new concept of the State (Stolzi, 2014, pp. 153-155).
Right from the outset there were glaring ambiguities. The new social actors were accorded recognition and full legal status, but in the same breath the non-interference pact between State and society was officially rescinded. In theory at least, this trend seemed as though it might pave the way for recognition of the private/social origin of law; in actual fact, its aim was to make the State the sole arbiter of collective life. The main influence behind the 1926 law, Alfredo Rocco, was quite clear that any opening towards a new legal framework for social organisations would be matched by a reorganisation of state power. $^{3}$

Society was seen as somehow "outside" the State, and rules were drawn up to control and limit its independence. While it is true, in Rocco's words, that State authority and power did not mean "bullying and undue interference", the fascist perspective nonetheless implied "the assertion that State goals were superior to those of lesser bodies and individuals" (Rocco, 1938, p. 478).

Hence this was by no means a decentralising of state authority, nor full recognition of the legal independence of the social dimension. There was no room for inroads "beyond the State". In other words, all forms of pluralism were brought within the framework of the State. In Rocco's view, accepting the force of self-organisation by society was not to lead to organisms being set up that might "outweigh the State" (Stolzi, 2007, p. 27). As he remarked in November 1920, the new social ferment formed a threat to the State: "The State is in a crisis; day by day, the State is dissolving into a host of lesser units, parties, associations, leagues, unions, that tie it down, paralyse it, stifle it" (Rocco, 1938, p. 631).

The case of the trade-unions was emblematic in this respect: their private-law statute was absorbed into the public domain of the State. That union organisation was recognised, but it needed disciplining. Intermediate social organisations lying halfway between the State and private individuals became an interlocutor with state power, but were subordinate to state authority. This got round the danger that the vigour of social dynamics might lead to a regulatory framework in competition with the State. The movement to organise private interests, at first seen as a threat to the State, now became an important "governing resource" (Stolzi, 2007, p. 108).

\section{The Legal Scholar's Point of View}

Fascism's idea of corporativism was designed to bridge the gap in the liberal model whereby power and the individual were kept apart. It made much of the claim to be part of a project: the State proclaimed itself the fruit of radical revising of the basic structures of the traditional legal set-up. Rocco had this in mind when he emphasised that the 1926 Charter of Labour was "the most profound transformation the State had undergone since the French Revolution" (Rocco, 1938, p. 335).

\footnotetext{
${ }^{3}$ A member of the nationalist movement, Alfredo Rocco (1875-1935) joined fascism in 1923. He was Minister of Justice (1925-1932). For a reconstruction of his thought see D'Alfonso (2004), Simone (2012), Speciale (2012), Chiodi (2015).
} 
Italian legal thinking was divided over the launching of this experiment. A large part, most closely linked to tradition, had little faith that the corporative revolution would reform the coordinates of the juridical system. Authors like Vittorio Emanuele ${ }^{4}$ Orlando or Salvatore Pugliatti $^{5}$ refused to believe that the nascent corporative system was really capable of overthrowing the traditional model of coexistence, based as that was on sharp separation between private and public, contractual freedom and general interest. For such jurists, recognition of the State's active new role in the social and economic sphere did not imply any substantial change in the ratio between private and public power as nineteenth-century tradition had handed it down.

Another faction took the opposite view: that here was a project that would truly demarcate new boundaries for the private and public spheres.

\subsection{Full-Scale Statism Versus Trade-Unionism}

One of the clear leaders in this debate was Giuseppe Bottai $^{6}$. In the years when the corporative system was being set in place he held a series of important political posts and would afterwards unceasingly ponder (and criticise) the course that the corporation experiment was taking. To Bottai, corporativism was indeed the way round the old forms of statism. To emerge from the impasse, the State should revert to being "the supreme organiser of the social side" (Stolzi, 2007). The behaviour of the groups into which mass society had fallen was something to govern, so as to prevent them getting out of hand or giving rise to forms of power in competition with the State. But it was a way round the old strategies by which the State had hitherto guided and stemmed the pressures of society: the solution could not lie in simple centralisation of administration or increasing control measures over the doings of intermediate bodies. To Bottai the State's role was not to guide, but to take a new lead in economic and social affairs. To do so it needed new bodies specifically appointed to run society and meanwhile bolster the authority of the overall State (Bottai, 1934).

The way previous statism was reformed was by radicalising it. The basic unit of State ceased to be the individual; the new centre was the corporation and trade-union, which promised to harness social forces with State powers. The unions ceased to be seen as a threat to public power: to Bottai (and also Panunzio) ${ }^{7}$ they and the corporations became the fulcrum of that new link between State and society and that new concept of sovereignty which was meant to rest upon social organisations. In this sense, Bottai argued, the corporative State was the fateful outcome of modern history and the death-knell of those French Revolutionary principles whereby the individual was ensured independence and freedom from the State (Bottai, 1934, p. 569).

Recognition of social formations was one way of shortening the distance between the individual and authority, yet ultimately the regime did not accord the intermediate forms of organisation any real regulatory independence. The unions and corporations were not allowed to regulate their own lives, let alone relations with the rest of society and the institutions. The gap separating society from authority would hence be reduced by absorbing the former into the State. Demiurgic state power thus ended by depotentiating the social organisations and robbing them of all the trappings of normative authority. Social forces' self-regulatory power was nothing more than formal, actually ignored in order to avoid the existence of normative powers other than the State itself.

Bottai and Panunzio reacted vigorously at this betrayal by Fascism of the corporative ideal (Stolzi, 2007, pp. 134-167). The corporations gradually grew more bureaucratic, and over the years this deprived the intermediate formations of independence and clout, such that they were quickly encroached on by state power. The fascist regime-charged Bottai-had compressed the social dialectics that it ostensibly wished to promote, in doing which it had taken a leaf out of the old liberal State's book.

\subsection{Corporative Idealism: Society to Identify with the State}

One of the most radical visions of the corporative venture stemmed from idealist philosophy. To authors like Ugo Spirito ${ }^{8}$ and Arnaldo Volpicelli, ${ }^{9}$ shortening the gap between State and individual was meant to come about when the two parties identified and the individual's interests were absorbed in public dynamics. The starting assumption-that the traditional framework of social coexistence represented a social deficit-was one they

\footnotetext{
${ }^{4}$ Vittorio Emanuele Orlando (1860-1950) was the founder of the Italian school of public law, a discipline that he helped set on a theoretical basis. He was not only the most representative jurist of liberal Italy, but also a highly experienced politician who held important posts in government between 1916 and 1920; cf. Cianferotti (1980), Fioravanti (2001).

${ }^{5}$ Salvatore Pugliatti (1903-1976) was one of the most sensitive voices in Italian juridical science; cf. Grossi (2002, pp. 95-119).

${ }^{6}$ Giuseppe Bottai (1895-1959) was one of the most active fascist intellectuals and held many political posts (governor of Rome, governor of Addis Abeba, minister of corporations, education minister). As Sabino Cassese wrote, "Bottai was a keen commentator on corporation activity....In such articles he constantly mentioned the political side to corporations as distinct from the technical aspect of the unions; he was concerned to show that corporativism was not the fruit of arbitrary improvisation but matured out of the crisis of the liberal State; his was a 'statist' approach, and critical of 'mixed unions'"; cf. Cassese (1971).

7 The jurist Sergio Panunzio (1886-1944) was a keen observer of the fascist movement in which he became one of the most influential theoreticians and technicians. His theory of the fascist State hinged on corporativism. On Panunzio, see Cavallari (1986).

${ }^{8}$ Giovanni Gentile's pupil Ugo Spirito (1896-1979) was a leader in the inter-war philosophical debate. He joined fascism's cultural project and tried to provide corporativism with a theoretical basis. For a reconstruction of his intellectual career, see Dessì (2009).

${ }^{9}$ Arnaldo Volpicelli (1892-1968) was a leading light in the inter-war debate addressing relations between State and society. He studied the philosophy of law under Gentile, and saw corporativism as a way of surmounting the crisis of political and legal modernity; cf. Franchi (2003).
} 
shared with other theoreticians of State crisis; but they proposed different ways out of it. The limitations of State could be surmounted not by focusing on regulation of social groups, but by extending ad infinitum the weight, roles and geometry of state power.

Spirito's "full-scale corporativism" (corporativismo integrale) reflected a radical organicistic standpoint by which even the trade-unions-that bulwark of social independence-constituted a limit on the normalising effect that State authority was meant to exert upon social dynamics (Breschi, 2010). There was no trace of that rhetorical pluralist ambiguity found in other interpretations of the corporative phenomenon. In short, the individual, along with the intermediate formations, should identify with and be absorbed into the State.

On this view of corporativism, society could not be given the power to regulate itself or generate independent forms of regulation. Society could not devise legal systems parallel or alternative to those of the State, since society could only be envisaged via the State (Stolzi, 2007, p. 186). The intermediate area of the social coexistence-the weak link in the chain of individual-society-State-could but surrender itself to the all-inclusive embrace of the State.

To Spirito and Volpicelli the merging of the individual with the State would reach its acme with the socalled "proprietary corporation"; the complete disappearance of private law and the idea of private interest before the boundless claims of public law. It was a necessary step-argued Spirito-since under fascism "private and public, individual and State had got entangled without really merging and ended up by widening the gap between them" (Spirito, 1932, p. 136). A gap which was to be bridged by absorbing the private into the public.

\subsection{Voices of Dissent: The Search for a New Balance between Private and Public}

Not everyone thought that corporativism need spell the end of private and social independence, or that putting the collective back centre-stage to resolve the private/public dichotomy need only favour the State. Certainly not the jurists who-we mentioned earliersought to interpret the new by tools of traditional legal doctrine. And certainly not Santi Romano or those like him who had all along been sensitive to the hybrid, composite quality of contemporary legal thinking. ${ }^{10}$ Even many jurists who sided politically with the regime felt that the solution could not be to turn individuals (and social formations) into organisms of the State.

There could be no arguing as to the centrality of the State, of course. But, to one faction of legal theory, law was not to be "tied up within the regulations" (Stolzi, 2012c), while the private-public tandem could not be resolved within the monochrome framework of the State. Authors like Widar Cesarini Sforza, ${ }^{11}$ Lorenzo Mossa, ${ }^{12}$ Enrico Finzi, ${ }^{13}$ Francesco Carnelutti ${ }^{14}$ or Ludovico Barassi ${ }^{15}$ were all for shaking free of the doldrums of traditional liberalism, but not to the point of absolutising the State in the dynamics of the law.

Romano should be harkened to, and his warning that organised interests and their potential for regulatory independence should be the linchpin around which to build a new juridical paradigm, a new ratio between individual, society and State catering for an extra-State dimension to the law. Cesarini Sforza's proposal stoutly upheld the collective arm of the law which promised a possible point of encounter between the bid for social autonomy and the guiding control of public power over private enterprise. The potential conflict between state and private interest should be resolved within the collective legal arena which that philosopher of law saw as "more than private and less than public" (Sforza, 1942, p. 189). To Cesarini Sforza the corporative system offered a real tertium in legal terms, being so constituted as to safeguard the private dimension without being absorbed lock, stock and barrel in state law. As he would write in 1942, "besides private and public interest, there is collective interest, an idea bound up with recognising the existence of 'social bodies', or organized groups creating legal set-ups and not just manifestations of contractual autonomy (Sforza, 1942, p. IV).

In other words, the distinction between public and private should be retained, though clearly the modern State was evolving towards primacy for the claims of public power. In this respect there was agreement among the various legitimating models forming the theoretical basis of the corporative system. In general it may be said that "the dialectics of autonomy and heteronomy...should comprise not only the law of inner life within the various social groups, but, still more, the new criterion for relationship between the private-social universe and the public-authoritative universe" (Stolzi, 2012c, p. 502). State intervention in the economy was a reality from the wartime years on: it was a road down

\footnotetext{
10 Romano's standpoint on the union and corporation model as proposed by Rocco was not all that critical. Romano's pluralism blended with a Statecentred vision of law. Thus, intermediate communities (corporations, trade unions, organizations) were a functional part of the State and were to be brought under its guidance, but should not be crushed or identified with the State; cf. Costa (1986, pp. 134ff.).

${ }^{11}$ Widar Cesarini Sforza (1886-1965) was an influential philosopher of law from the idealist school. Corporativism was one of his main areas of research; cf. Costa (1976-1977).

12 The professor of commercial law, Lorenzo Mossa (1986-1957), ranged in his thinking outside the bounds of traditional liberal formalism. Despite his broadly antifascist stance, he recognised the regime's merit in revising labour law; cf. Stolzi (2012b).

${ }^{13}$ Enrico Finzi (1884-1973) was one of the finest minds in private law and focused on the developments in the law of ownership; cf. Stolzi (2012a); Grossi (2013).

${ }^{14}$ Francesco Carnelutti (1879-1965) was an influential expert in civil trial law. He helped draw up the 1940 code of civil procedure; cf. Grossi (2000).

15 Ludovico Barassi (1873-1961) was one of the fathers of labour law in Italy. Under fascism he added commentary on corporative to that on civil law; cf. Passaniti (2012).
} 
which one might venture further, but which should not entail the extreme sacrifice of social independence.

Part of Italian legal thinking thus worked to undermine corporativism from inside, or rather that part of the corporative venture which seemed bent on overradical compression of individual independence. Theoretical skirmishing over the private side to collective bargaining (Barassi, 1939), the exact nature of union representation (Pugliatti, 2008), or the limits to the public dimension of property (Finzi, 2013) served one purpose in reality: to safeguard as far as possible the mainstays of private independence, especially contract and property. The new framework of social coexistence afforded by corporativism was not rejected, but limits should be set to the private being swallowed up by the State, or the individual and intermediate organisations being transformed into intrinsic units of State. The crisis of the individualist model was plain to behold, and so was the process of gradual "publicizing" of legal dynamics; but some jurists staunchly defended the central role of the individual which, despite his collective implications, he might and should preserve.

To authors like Finzi, Cesarini Sforza, Mossa or Capograssi corporativism was a mechanism by which to surmount the limitations of liberal statism, whilst ensuring a disciplined independence for the unstoppable formation of interest groups and social organisations lying halfway between the private and the public. The corporativist venture need not be pursued to its totalitarian extreme; suffice it to make room for a legal form which stemmed from social coexistence, however much it might be channelled within a state framework.

Focusing on the collective aspect of law, as Cesarini Sforza pointed out, would enable "the idea of law to remain free of the State", and the existence of infrastate legal channels to have a recognised existence ${ }^{16}$. To some, like Finzi, this meant giving real content to revolutionary principles from 1789 , setting organised interests and the social plane centre-stage and providing a midway version of law - not just state-dominated or only private-at a time when the State was necessarily intervening in the role of protagonist. ${ }^{17}$ In this respect organising the State into unions and corporations would enable a "point of equilibrium" to be struck between social activity and individual power over things, which redounds to the well-being and power of the Nation" (Finzi, 2013, p. 68).

There were others, like Mossa, who saw enterprise as the lever by which to keep private and public in communication, and to give independence and a central position to the collective, without it being absorbed wholesale by the State. ${ }^{18}$ The institutions overhauled by the new system (from collective contract to corporative regulations) should thus be the concrete tools around which to create new forms of regulation, and hence an intermediate juridical arena midway between autonomy and heteronomy (Stolzi, 2007, pp. 392-424).

\section{Conclusions}

As the latest historical thinking has shown, corporativism was not just a bluff (Santomassimo, 2006, p. 16). Manoilesco's forecast did not come true (the Romanian scholar had suggested that the twentieth century would be the century of corporativism) (Manoilesco, 1937). The experiment was not just chicanery, even in the authoritarian fascist version. There is, of course, an enormous gap between the words and theory that dressed it, and the concrete product of the corporative revolution which spawned, not a corporative State, but a bureaucratic State (Mazzoni, 1943, p. 117; Sforza, 1942, pp. 279-287). That gap reveals a paradox: that a doctrine stemming from the attempt to give the new social relations central importance and independence (including normative independence) should have slid so quickly into diehard statism bent on eliminating all forms of competition with the State. In that sense some in particular maintain that corporativism was an enormous rhetorical hoax. Indeed, the storytelling it spawned is riddled with contradiction and ambiguity: first and foremost, how the ostensible attempt to rewrite the extra-state coordinates of the legal system and give regulatory independence to groups of manufacturers actually led to the establishment of a state-based legal system.

Insofar as the intention (going by the confused and contradictory claims of the would-be reformers) was to give rise to a new kind of state system enabling the earlycentury crisis to be surmounted, corporativism was indeed an ill-fated experiment: the demand for regulatory independence by organised groups was absorbed into a heavily State-run system. It does remain a highly interesting area for analysis, however: first, for the wealth of theory that it engendered, and second, for the clash between its starting premises (upholding union autonomy, transcending the public/private dichotomy, recognising the authority of new social formations) and the effects it led to (authoritarianism, bolstering of the State, absorbing of social dynamics into public structures).

\section{Conflict of Interests}

The author declares no conflict of interests.

\footnotetext{
16 To Cesarini Sforza "collective law" was a step above private law but was not to all effects public law; it formed an "intermediate level" between private and public which detracted from harmonious co-existence between them; cf. Cesarini Sforza (1942, pp. 189-190).

17 Recognising the public law quality of erstwhile private law forms part of this interpretative trend. As Grossi wrote, "Finzi, who is no fascist, is a keen observer of the corporativist movement, his attitude being...to remove the cluttering and superfluous tinsel that fascist officialdom foisted on it and to detect its many similarities with the transition in progress, which he collected and arranged into an innovative scientific argument" (Grossi, 2013, p. XXXVI).

18 On Mossa's attempt to prevent the whole juridical area being absorbed and reduced inside the bounds of "overweening public law", see his lecture Notion, Assumptions and Purpose of Economic Law, delivered in 1934 at the University of Santander and later collected in Mossa (1935, p. 96).
} 


\section{References}

Barassi, L. (1939). Diritto corporativo e diritto del lavoro. Milan: Giuffrè.

Bottai, G. (1934). Esperienza corporativa. Florence: Vallecchi.

Breschi, D. (2010). Spirito del Novecento. Il secolo di Ugo Spirito dal fascismo alla contestazione. Soveria Mannelli: Rubbettino.

Cassese, S. (1971). Giuseppe Bottai. In Dizionario biografico degli Italiani (pp. 389-404). Rome: Enciclopedia Italiana.

Cassese, S. (2012a). La prolusione romaniana sulla crisi dello Stato moderno e il suo tempo. Le Carte e la Storia, 1, 5-8.

Cassese, S. (2012b). Lo Stato fascista. Bologna: il Mulino.

Cavallari, G. (1986). Pluralismo e gerarchia nel pensiero filosofico-politico di Sergio Panunzio. In A. Mazzacane (Ed.), I giuristi e la crisi dello Stato liberale in Italia tra Otto e Novecento (pp. 413-428). Naples: Liguori.

Cazzetta, G. (2007). Scienza giuridica e trasformazioni sociali. Diritto e lavoro in Italia tra Otto e Novecento. Milan: Giuffrè.

Cerasi, L. (2001). Corporatismo/corporativismo e storia d'Italia. Una questione aperta? Un percorso di lettura. Contemporanea, 2, 367-377.

Chiodi, G. (2015). Alfredo Rocco e il fascino dello Stato totale. In I. Birocchi \& L. Lochiamo (Eds.), I giuristi e il fascino del regime (1918-1925) (pp. 103-127). Rome: RomaTrE-Press.

Cianferotti, G. (1980). II pensiero di Vittorio Emanuele Orlando e la giuspubblicistica italiana tra Otto e Novecento. Milan: Giuffrè.

Collin, P., Bender, G., Ruppert, S., Seckelmann, M., \& Stolleis, M. (Eds.). (2014). Regulierte Selbstregulierung in der westlichen Welt des späten 19. und frühen 20. Jahrhunderts. Frankfurt am Main: Klostermann.

Costa, P. (1976-1977). Widar Cesarini Sforza: Illusioni e certezze della giurisprudenza. Quaderni Fiorentini per la Storia del Pensiero Giuridico Moderno, 5/6, 1031-1095.

Costa, P. (1986). Lo stato immaginario. Metafore e paradigmi della cultura giuridica italiana fra Ottocento e Novecento. Milan: Giuffrè.

D’Alfonso, R. (2004). Costruire lo Stato forte. Politica, diritto, economia in Alfredo Rocco. Milan: Franco Angeli.

Dessì, G. (2009). Ugo spirito. Filosofia e rivoluzione. Milan: Luni.

Finzi, E. (2013). "L'officina delle cose". Scritti minori. Milan: Giuffrè.

Fioravanti, M. (2001). La scienza del diritto pubblico. Dottrine dello Stato e della Costituzione tra Otto e Novecento. Milan: Giuffrè.

Franchi, G. (2003). Arnaldo Volpicelli. Per una teoria dell'autogoverno. Naples: Editoriale Scientifica.

Gagliardi, A. (2010). I/ corporativismo fascista. Rome and Bari: Laterza.
Grossi, P. (2000). Scienza giuridica italiana. Un profilo storico 1860-1950. Milan: Giuffrè.

Grossi, P. (2002). La cultura del civilista italiano. Milan: Giuffrè.

Grossi, P. (2011). Lo Stato moderno e la sua crisi (a cento anni dalla prolusione pisana di Santi Romano). Rivista Trimestrale di Diritto Pubblico, 1, 1-22.

Grossi, P. (2012). Il diritto nella storia dell'Italia unita. Naples: Editoriale Scientifica.

Grossi, P. (2013). Enrico Finzi: Un innovatore solitario. In E. Finzi (Ed.), "L'officina delle cose". Scritti minori (pp. V-LII). Milan: Giuffrè.

Laborde, C. (1996). Pluralism, syndicalism and corporatism. Léon Duguit and the crisis of the State. History of European Ideas, 22, 227-244.

Luongo, A. (2013). Lo Stato moderno in trasformazione. Momenti del pensiero giuridico Italiano del primo Novecento. Turin: Giappichelli.

Manoïlesco, M. (1937). Le siècle du corporatisme. F. Alcan. Marchetti, P. (2006). L'essere collettivo. L'emersione della nozione di collettivo nella scienza giuridica italiana tra contratto di lavoro e Stato sindacale. Milan: Giuffrè.

Mazzacane, A. (Ed.). (2002). Diritto economia e istituzioni nell'Italia fascista. Baden Baden: Nomos.

Mazzacane, A., Somma, A., \& Stolleis, M. (Eds.). (2005). Korporativismus in den südeuropäischen Diktaturen. Frankfurt am Main: Klostermann.

Mazzoni, G. (1943). La "crisi" del diritto corporativo e la validità del corporativismo. I/ Diritto del Lavoro, 1, 117-134.

Mossa, L. (1935). L'impresa nell'ordine corporativo. Florence: Sansoni.

Panunzio, S. (1987). Il fondamento giuridico del fascismo. Rome: Bonacci.

Passaniti, P. (2012). Lodovico Barassi. In I/ contributo Italiano alla storia del pensiero-Diritto (pp. 430-433). Rome: Enciclopedia Italiana.

Pugliatti, S. (2008). Dalla obbligazione in solido alla rappresentanza sindacale. In S. Pugliatti (Ed.), Scritti giuridici (pp. 17-42). Milan: Giuffrè.

Ripepe, E. (2012). La teoria dell'ordinamento giuridico: Santi Romano. In // contributo Italiano alla storia del pensiero. II Diritto (pp. 475-484). Rome: Enciclopedia Italiana.

Riquelme, S. F. (2010). Corporativismo y sociología en Émile Durkheim. Apuntes de política social. Nonnullus. Revista Digital de Historia, 6, 63-82.

Rocco, A. (1938). Scritti e discorsi politici. Milan: Giuffrè. Romano, S. (1950). Scritti minori. Milan: Giuffrè.

Santomassimo, G. (2006). La terza via fascista. II mito del corporativismo. Rome: Carocci.

Schiera, P. (2005). Corporativismo: Concetti storici. In A. Mazzacane, A. Somma, \& M. Stolleis (Eds.), Korporativismus in den südeuropäischen Diktaturen (pp. 4447). Frankfurt am Main: Vittorio Klostermann.

Schmitter, P. C. (1974). Still the century of corporatism? Review of Politics, 1, 85-131. 
Schmitter, P. C. (1992). Corporativismo/corporatismo. In Enciclopedia delle scienze sociali (pp. 458-468). Rome: Istituto dell'Enciclopedia Italiana Treccani.

Sforza, W. (1942). Il corporativismo come esperienza giuridica. Milan: Giuffrè.

Simone, G. (2012). Il guardasigilli del regime. L'itinerario politico e culturale di Alfredo Rocco. Milan: Franco Angeli.

Speciale, G. (2012). Alfredo Rocco. In I/ contributo Italiano alla storia del pensiero-Diritto (pp. 559-562). Rome: Enciclopedia Italiana.

Spirito, U. (1932). Individuo e Stato nella concezione corporativa. In Atti del Secondo convegno di studi sindacali e corporativi (pp. 179-192). Rome: Tipgrafia del Senato.

Stolzi, I. (2007). L'ordine corporativo. Poteri organizzati e organizzazione del potere nella riflessione giuridica dell'Italia fascista. Milan: Giuffrè.

Stolzi, I. (2009). Corporativismo autoritario e neocorporativismi: Modelli teorici a confronto. In G. G. Ballando \& G. Cazzetta (Eds.), Diritti e lavoro nell'Italia repubblicana (pp. 159-181). Milan: Giuffrè.

Stolzi, I. (2012a). Enrico Finzi. In I/ contributo Italiano alla storia del pensiero-Diritto (pp. 533-536). Rome: Enciclopedia Italiana.
Stolzi, I. (2012b). Lorenzo Mossa. In // contributo italiano alla storia del pensiero-Diritto (pp. 529-533). Rome: Enciclopedia Italiana.

Stolzi, I. (2012c). Stato corporativo. In II contributo italiano alla storia del pensiero-Diritto (pp. 497-503). Rome: Enciclopedia Italiana.

Stolzi, I. (2014). Private, public and collective: The twentieth century in Italy from fascism to democracy. In M. Rask \& C. Thornhill (Eds.), Law and the formation of modern Europe. Perspectives from the historical sociology of law (pp. 145-178). Cambridge: Cambridge University Press.

Tarello, G. (1979). Corporativismo. In A. Negri (Ed.), Enciclopedia Feltrinelli Fischer, scienze politiche, I (Stato e politica) (pp. 68-81). Milan: Feltrinelli.

Tarello, G. (1988). II termine "corporativismo" e le sue accezioni. In G. Vardaro (Ed.), Diritto del lavoro e corporativismi in Europa: leri e oggi (pp. 35-49). Milan: Franco Angeli.

Vallauri, C. (1971). Le radici del corporativismo. Rome: Bulzoni.

Vassalli, F. (1939). Studi giuridici, II. Rome: Società Editrice del Foro Italiano.

\section{About the Author}

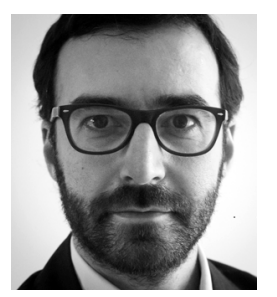

Maurizio Cau (1974) is researcher at the Italian-German Historical Institute in Trento. His research interests focus on history of contemporary European political thought and history of Italian and German constitutionalism in the twentieth century. Among his publications are Politica e Diritto: Karl Kraus e la Crisi della Civiltà (il Mulino, 2008); L’Europa di De Gasperi e Adenauer: La Sfida della Ricostruzione (il Mulino, 2011); and with G. Pallaver, Geschichte und politischer Konsens: Übergänge der Nachkriegszeit (1945-1955), (Duncker \& Humblot, 2014). 